\title{
Actinomycin D Induces Phosphorylation of STAT3 through Down-Regulation of SOCS3 in Renal Cancer Cells
}

\author{
Seon Min Woo, Eun Jung Park and Taeg Kyu Kwon* \\ Department of Immunology, School of Medicine, Keimyung University, Daegu 704701, Korea
}

Received December 27, 2010 / Accepted January 12, 2011

\begin{abstract}
Actinomycin D is a natural antibiotic that is used in anti-cancer chemotherapy and is known as a transcription inhibitor. Interestingly, actinomycin D induces phosphorylation of signal transducers and activators of transcription 3 (STAT3) in renal cancer Caki cells. In this study, we examined the molecular mechanism of actinomycin D-induced STAT3 phosphorylation. Treatment with actinomycin D induced phosphorylation of STAT3 (Tyr705) in a dose- and time-dependent manner. However, actinomycin D did not induce phosphorylation of STAT3 (Ser727), STAT1 (Tyr701) and STAT1 (Ser727). Moreover, actinomycin D-induced STAT3 phosphorylation was caused by decreased protein and mRNA levels of SOCS3, but not by JAK2 and SHP-1. In addition, other transcription inhibitor (5,6-dichloro-1-b-D-ribofuranosyl benzimidazole; DRB) also induced phosphorylation of STAT3 (Tyr705). Taken together, the present study demonstrates that transcriptional inhibitors (actinomycin D and DRB) induce phosphorylation of STAT3 (Tyr705) in Caki cells by down-regulation of SOCS3.
\end{abstract}

Key words : Actinomycin D, STAT3, SOCS3, Caki cells

\section{서 론}

Actinomycin D는 Actinomycins group에 속하는 항생물질 로 dactinomycin 또는 cosmegen 이라고도 한다. 세포 독성과 항종양성을 가진다고 알려져 있으며 암세포의 DNA에 작용하 는 항암제로 알킬화제에 포함된다[12,13]. Actinomycin D는 세포자멸사(apoptosis)를 일으키는 강력한 유도물질로 DNA 에 결합하여 유전 정보 전사를 저해한다[8, 13]. 이들 유사 약물 은 생식세포종양(germ cell tumors), 연조직육종(soft-tissue sarcoma), 흑색종(melanoma), 융모암종(choriocarcinoma) 등 의 치료에 사용되는 항암 화학 치료 약물이다. Actinomycin $\mathrm{D}$ 의 작용기전은 낮은 농도 $(0.01-0.05 \mu \mathrm{g} / \mathrm{ml})$ 에 서는 전사작용 을 억제 하지만 높은 농도 $(>1 \mu \mathrm{g} / \mathrm{ml})$ 에서는 세포자멸사 (apoptotic cell death)를 유도 한다[6,21]. 또한 actinomycin D 는 매우 낮은 농도 $(1 \mathrm{nM})$ 에서 Shc/Grb2의 상호작용을 제해하 므로 G1기의 arrest를 유도 하였다[10]. 하지만 Shc/Grb2의 상호 작용의 저해는 $10 \mathrm{nM}$ actinomycin $\mathrm{D}$ 에서 관찰 되므로 새로운 다른 기전의 존재함을 제시하여 준다.

Signal transducer and activator of transcription 3 (STAT3) 은 STAT family 중 하나로 세포질 내에서 비활성형으로 존재 하다가 여러 가지의 사이토카인(cytokine)이나 성장인자 (growth factor), 호르몬의 자극 등에 의해 인산화가 일어난 뒤 이합체(dimer)를 형성한 후 핵 내로 이동하여 신호를 전달 하는 전사조절인자(transcription factor)이다[7,9,19]. STAT3

*Corresponding author Tel : +82-53-580-3882, Fax : +82-53-580-3795

E-mail : kwontk@dsmc.or.kr
는 다양한 종류의 유전자 발현을 조절함으로써 세포의 분화, 생존, 증식, 사멸 등을 유발시키며, 특히 많은 종양세포에서 발현이 증가하는 것으로 알려져 있다[16]. STAT3의 활성은 STAT3 인산화를 촉진하는 STAT의 upstream kinase인 Janus kinase 2 (JAK2)의 인산화와 JAK2와 결합하여 활성을 억제하 는 suppressor of cytokine signaling 3 (SOCS3) 단백질 발현정 도와 tyrosine phosphatase인 $\mathrm{SH} 2$ domain-containing protein tyrosine phosphatase (SHP-1)의 활성에 의해서 조절 된다 [1]. JAK2는 interferon- $\gamma$ (IFN- $\gamma$ )의 신호전달에서 중요한 역할 을 하며 사이토카인 수용체의 하류에서 세포의 기능 조절에 중요한 전사인자인 STAT의 인산화를 유도한다[17,18,22]. $\mathrm{SOCS} 3$ 는 STAT를 억제하거나 JAK 활성과 관련된 수용체를 억제하고 사이토카인 신호 전달계 조절에 중요한 역할을 한 다. 또한 SOCS3 유전자는 interleukin-6 (IL-6)의 중요한 조절 인자로 IL-6에 의한 STAT3의 활성을 억제한다고 알려져 있다 $[3,15,18,23,25]$. SHP-1은 tyrosine잔기의 인산기의 탈인산화를 통해 신호전달을 음성적으로 조절한다[5,18,20,24].

본 연구에서는 전사억제제(transcription inhibitor)로 알려 져 있는 actinomycin D를 처리 시 특이적으로 STAT3가 인산 화 되는 것을 확인하였다. Actinomycin D에 의해 유도되는 STAT3 인산화는 JAK2 활성을 저해하는 SOCS3 단백질의 발 현 감소에 의하여 야기됨을 확인하였고, STAT3의 탈인산화를 유도한다고 알려진 tyrosine phosphatase인 SHP-1 발현과 무 관하였다. 또한 다른 전사 저해제에서도 동일한 현상을 확인 하였다. 


\section{재료 및 방법}

\section{세포 배양 및 시약}

본 연구에 사용한 신장암세포주인 Caki는 American Type Culture Collection (ATCC, Rockville, MD, USA)에서 구입하 였다. 세포주 배양을 위한 배지는 $10 \%$ 태아우혈청(fetal bovine serum, Hyclone laboratories, Lagan, Utah, USA)과 1\% Antibiotics, $0.2 \%$ Gentamycin을 첨가한 DMEM (Dulbecco's Modified Eagle's Medium, Gibco BRL, Grand Island, NY)을 사용하였으며 $37^{\circ} \mathrm{C}$ 로 유지되는 $5 \% \mathrm{CO}_{2}$ 배양기를 이용하여 배양하였다. 실험에 사용된 약제인 actinomycin D와 DRB는 Sigma (St. Louis, MO, USA)에서 구입하였다.

\section{Western blotting}

단백질의 발현을 알아보기 위해서 Western blot을 실시하 였다. 세포를 $0.45 \times 10^{6}$ cells/well로 12 시간 배양 후에, FBS를 첨가하지 않은 무혈청 배지로 교체하여 시약을 처리하여 배 양 후, 세포를 모아 $32 \mu \mathrm{l}$ lysis buffer $(137 \mathrm{mM} \mathrm{NaCl}, 15 \mathrm{mM}$ EGTA, $0.1 \mathrm{mM}$ sodium orthovanadate, $15 \mathrm{mM} \mathrm{MgCl} 2,0.1 \%$ Triton X-100, $25 \mathrm{mM}$ MOPS, $100 \mathrm{mM}$ phenylmethylsulfonyl fluoride, and $20 \mathrm{mM}$ leupeptin, $\mathrm{pH}$ 7.2)를 첨가하고 5 분 간 격으로 15 초 동안 3 번 vortex하여 세포를 파쇄한 후 13,000 $\mathrm{rpm}, 4^{\circ} \mathrm{C}, 15$ 분간 원심분리하여 시료를 준비하였다. 시료는 $562 \mathrm{~nm}$ 에서 흡광도를 측정하여 단백질을 정량하였으며, $10 \%$ sodium dodecyl sulfate polyacrylamide gel electrophoresis (SDS-PAGE)에서 단백질을 분리한 후, immobilon membrane (Milipore, Bedford, MA, USA)으로 transfer하였다. Membrane은 5\% milk/TBST (20 mM Tris- $\mathrm{HCl}, 137 \mathrm{mM}$ $\mathrm{NaCl}, 0.1 \%$ Tween 20, pH 7.4)로 실온에서 1시간 유지한 후, p-STAT3, STAT3, p-STAT1, STAT1, SOCS3, p-JAK2, SHP-1, ERK (Santa Cruz, CA, USA)를 희석한 5\% milk/TBST로 실 온에서 12시간 유지하였다. Anti-mouse 또는 rabbit Ig horseradish peroxidase/TBST (Amersham Buckinghamshire, England)로 1시간 반응 후 Enhanced Chemiluminoscence (ECL, Pierce, IL, USA)용액을 가하여 발색시켜서 단백질 발 현을 확인하였다.

\section{역전사 중합효소 연쇄반응(RT-PCR)}

세포를 $0.45 \times 10^{6}$ cells/well로 12 시간 배양 후에, $\mathrm{FBS}$ 를 첨가 하지 않은 무혈청 배지로 교체하여 시약을 처리하여 배양 후, 세포를 모아 Trizol $700 \mu 1$ 를 첨가하고 chloroform $140 \mu \mathrm{l}$ 을 첨 가하여 $13,000 \mathrm{rpm}, 4^{\circ} \mathrm{C}, 15$ 분간 원심분리하여 시료를 준비하 였다. 상층액을 취한 후 동량의 isopropanol을 처리하여 $-20^{\circ} \mathrm{C}$ 에서 1시간 방치한 뒤 $13000 \mathrm{rpm}, 4^{\circ} \mathrm{C}$, 15분간 원심분리하여 $\mathrm{RNA}$ 를 침전시킨다. $70 \%$ 의 에탄올로 세척하고 DEPC-DW (Diethylpyrocarbonate-distilled water) $25 \mu \mathrm{l}$ 로 녹였다. 260 $\mathrm{nm}$ 에서 흡광도를 측정하여 RNA를 정량하였으며 MMLV RTase 와 RNase inhibitor를 이용하여 cDNA를 합성한 후, STAT3, SOCS3, Actin primer와 cDNA $2 \mu 1$ 를 이용하여 STAT3는 $95^{\circ} \mathrm{C}$ 에 서 45 초, $51^{\circ} \mathrm{C}$ 에서 45 초, $72^{\circ} \mathrm{C}$ 에서 45 초간 23 cycles으로 합성하 였고 SOCS3는 $95^{\circ} \mathrm{C}$ 에서 25 초, $55^{\circ} \mathrm{C}$ 에서 25 초, $72^{\circ} \mathrm{C}$ 에서 25 초간 27 cycles로 합성하였다. 합성된 STAT3와 SOCS3는 1\% Agarose gel에서 전기영동하여 확인하였다. 본 실험에 사용한 primer sequences (SOCS3; Forward-5'-CTGCGGGCTGGCGAAGG AAA， Reverse-5'-GCTGGCTTGGTGCCCTCCAG， STAT3; Forward-5'-GGAGCAGAGATGTGGGAATG， Reverse-5'CTTGGTGGTGGAGGAGAACT, Actin; Forward- 5'-GGCAT CGTCACCAACTGGGAC, Reverse-5'-CGATTTC CCGCT CGGCCGTGG)을 사용하였다.

\section{결과 및 고찰}

\section{신장암 Caki 세포주에서 actinomycin D에 의한 STAT3 의 인산화 조절}

Actinomycin D에 의한 신장암세포주에서 STAT3의 인산화를 확인하기 위하여 Caki 세포주에 actinomycin $\mathrm{D}$ 를 농도별, 시간 별로 처리하고 STAT3의 인산화를 확인하였다. Actinomycin D 를 농도별로 $1,3,5 \mu \mathrm{g} / \mathrm{ml}$ 을 4 시간 동안 처리한 후 Western Blotting 으로 STAT3의 Tyr705과 Ser727의 인산화를 확인하 였다. 그 결과 actinomycin D를 농도별로 처리 했을 때, STAT3 의 Tyr705의 인산화가 유도되는 것을 확인하였다(Fig. 1A). Actinomycin D를 $5 \mu \mathrm{gg} / \mathrm{ml}$ 을 시간별로 1, 2, 4 시간 동안 처리 한 후 Western Blotting으로 STAT3의 Tyr705과 Ser727의 인산 화를 확인한 결과, 시간별로 STAT3의 Tyr705 인산화가 유도 되는 것을 확인하였다(Fig. 1B).

\section{Actinomycin D에 의한 STAT1의 인산화 조절 여부}

Actinomycin D가 STAT family 중 STAT1의 인산화에 미치 는 영향을 조사하기 위하여 actinomycin D를 농도별로 1, 3, $5 \mu \mathrm{g} / \mathrm{ml}$ 을 4 시간 동안 처리한 후, Western Blotting으로 확인 하였다. IFN- $\gamma$ 를 STAT1의 활성화에 대한 positive control로 사용하였다. Actinomycin D에 의해 Tyr701 잔기의 인산화가 유도되지 않았지만 positive control인 IFN- $\gamma$ 에 의한 인산화 는 확인 하였다. STAT1의 Ser727의 인산화는 basal level에서 인산화를 확인 하였으나 actinomycin D 농도별 처리에 따른 인산화 증가를 확인 할 수가 없었다. 하지만 IFN- $\gamma$ 처리 시 STAT1의 Ser727 잔기의 인산화 정도가 더욱 증가함을 확인 하였다(Fig. 2). IFN- $\gamma$ 를 astrocyte 세포에 처리 시 STAT1과 STAT3의 인산화를 유도 한다[2]. 따라서 이상의 결과는 actinomycin D에 의한 STAT의 인산화 유도가 STAT3의 Tyr705 잔기 특이적으로 유도되고 IFN- $\gamma$ 와 다른 양상의 STAT 인산 화 과정을 보여준다. 
A

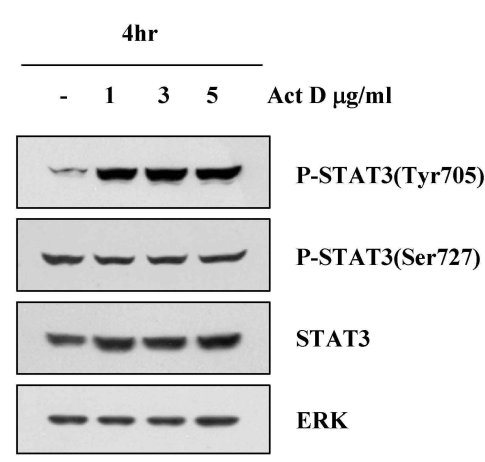

B

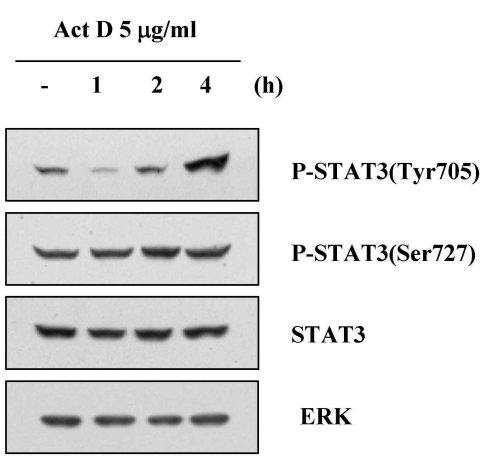

Fig. 1. Actinomycin D induces STAT-3 (Tyr705) phosphorylation in Caki cells. (A) Caki cells were incubated with 1, 3, $5 \mu \mathrm{g} / \mathrm{ml}$ actinomycin D for $4 \mathrm{hr}$. Cell lysates $(50 \mu \mathrm{g})$ were analyzed by SDS-PAGE and detected with specific antibodies, anti-p-STAT3 (Tyr705), anti-p-STAT3 (Ser727), and anti-STAT3 (total form). Equal protein loading was confirmed by ERK expression. (B) Caki cells were incubated with actinomycin D $(5 \mu \mathrm{g} / \mathrm{ml})$ for 1, 2, $4 \mathrm{hr}$. Cell lysates $(50 \mu \mathrm{g})$ were analyzed by SDS-PAGE and detected with specific antibodies, anti-p-STAT3 (Tyr705), anti-p-STAT3 (Ser727), and anti-STAT3 (total form). Equal protein loading was confirmed by ERK expression.

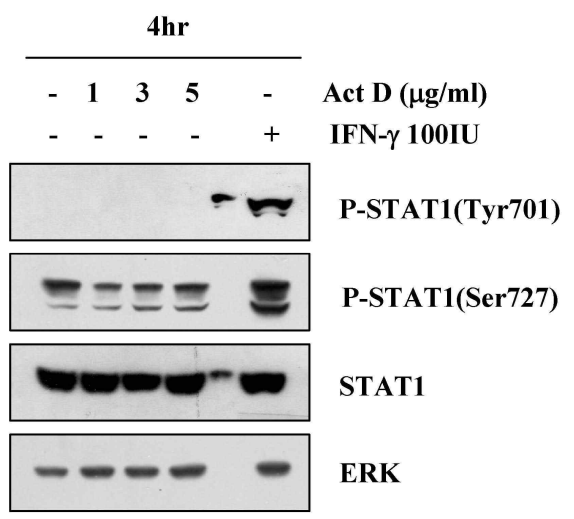

Fig. 2. Actinomycin D has no effect on STAT-1 phosphorylation in Caki cells. Caki cells were incubated with $1,3,5 \mu \mathrm{g} / \mathrm{ml}$ actinomycin D or IFN- $\gamma$ (100 IU) for $4 \mathrm{hr}$. Cell lysates(50 $\mu \mathrm{g})$ were analyzed by SDS-PAGE and detected with specific antibodies, anti-p-STAT1 (Tyr701), anti-p-STAT1 (Ser727), and anti-STAT1 (total form). Equal protein loading was confirmed by ERK expression.

Actinomycin D 처리에 의한 STAT3의 인산화 조절에서 의 SOCS3, SHP-1, JAK2의 관련성 여부

Actinomycin D 처리로 인해 STAT3의 Tyr705의 인산화가 증가한다는 것을 확인하였고, 이러한 actinomycin D에 의한 인산화 조절에 어떤 인자가 관여하는지 알아보고자 하였다. 이전의 보고에 의하면 STAT3의 인산화는 포스파타아제인 SOCS3, SHP-1에 의해 조절된다고 알려져 있으며, STAT의 upstream kinase인 JAK2의 인산화에 의해 STAT3의 인산화가 조절된다고 알려져 있다[1]. Actinomycin D를 농도별로 1, 3, $5 \mu \mathrm{g} / \mathrm{ml}$ 을 4 시간 동안 처리한 후 Western Blotting으로 $\mathrm{SOCS} 3$ 와 SHP-1의 발현정도와 JAK2의 인산화를 확인한 결과 SHP-1의 발현과 JAK2의 Tyr1007의 인산화 정도에는 변화를
확인 할 수가 없었다. 하지만 특이적으로 SOCS3의 발현이 actinomycin D 농도별로 감소하는 것을 확인하였다(Fig. $3 \mathrm{~A}$ ). $\mathrm{SOCS} 3$ 의 단백질 발현 감소가 전사단계인 $\mathrm{mRNA}$ 발현 정도를 RT-PCR 방법으로 확인한 결과 SOCS3의 mRNA 발현정도가 감소되는 것을 확인하였다(Fig. $3 \mathrm{~B}$ ). SOCS는 SOCS1-SOCS7이 알려져 있고 JAK와 결합하여 촉매작용을 억제하기도하고 cytokine receptor의 tyrosine 잔기의 인산화를 억제한다[18]. SOCS1과 SOCS3이 염증반응 및 IFN- $\gamma$ 신호전달계의 STAT1 과 STAT3의 인산화 과정에 결정적인 역할을 한다[4]. STAT3 의 mRNA 발현에는 actinomycin D가 아무런 영향을 주지 않 았다. 그렇지만 SOCS3의 전사 억제력이 $1 \mu \mathrm{g} / \mathrm{ml}$ actinomycin $\mathrm{D}$ 농도에서 야기됨을 확인하였다(Fig. $3 \mathrm{~B}$ ). 이는 actinomycin $\mathrm{D}$ 에 의한 유전자의 전사억제가 특이적으로 일어남을 제시하 여 준다.

\section{전사억제제인 DRB에 의한 STAT3의 인산화 조절 여부}

다른 전사억제제 처리 시에도 actinomycin $\mathrm{D}$ 와 같이 STAT3의 인산화 조절을 유도하는지를 확인하기 위해 전사억 제제인 DRB (5, 6-dichloro-1-b-D-ribofuranosyl benzimidazole)를 처리하여 실험을 진행하였다 $[7,10,18]$. Caki 세포에 $\mathrm{DRB}$ 를 농도 $(5-20 \mu \mathrm{M})$ 별로 4 시간 동안 처리한 후 세포를 수확 하여 Western Blotting으로 확인한 결과에서도 Fig. 4에서 actinomycin D에 의한 STAT3의 인산화 조절과 유사하게 STAT3의 Tyr705의 인산화가 증가하였다. 하지만 SHP-1과 STAT3 단백질 발현량에서는 변화가 없는 것을 확인하였다 (Fig. 4). 또한 SCOS3 단백질의 발현에는 actinomycin D가 유 사하게 감소함을 확인하였다. 이상의 결과는 유전자의 전사 억제제인 actinomycin D와 DRB에 의하여 특이적인 유전자의 전사 과정의 억제를 통하여 새로운 세포의 기능조절에 관여 할 수 있다는 가능성을 제시하여 준다. 또한 보다 더 추가적인 
A

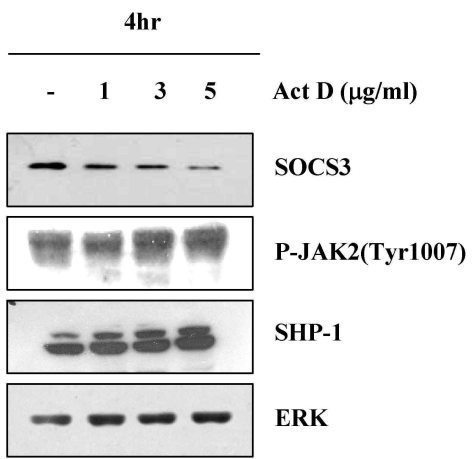

$\mathbf{B}$

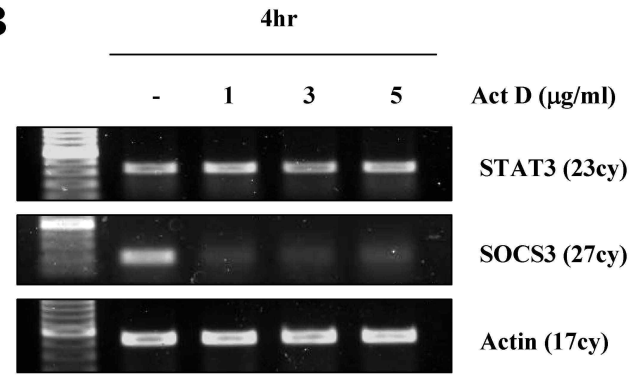

Fig. 3. Actinomycin D inhibits protein and mRNA expression of SOCS3. (A) Caki cells were incubated with 1, 3,5 $\mu \mathrm{g} / \mathrm{ml}$ actinomycin D for $4 \mathrm{hr}$. Cell lysates (50 $\mathrm{gg}$ ) were analyzed by SDS-PAGE and detected with specific antibodies, anti-SOCS3, anti-p-JAK2, and anti-SHP-1. Equal protein loading was confirmed by ERK expression. (B) Caki cells were incubated with 1, 3, $5 \mu \mathrm{g} / \mathrm{ml}$ actinomycin D for $4 \mathrm{hr}$. Total RNA was prepared and RT-PCR analysis was performed using STAT3- and SOCS3-specific primer. Equal mRNA loading was confirmed by actin expression.

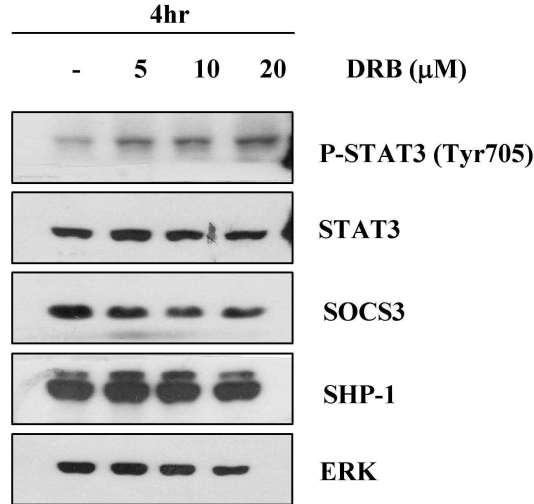

Fig. 4. DRB induces STAT-3 (Tyr705) phosphorylation in Caki cells. (A) Caki cells were incubated with 5, 10, $20 \mu \mathrm{M}$ DRB for $4 \mathrm{hr}$. Cell lysates (50 $\mu \mathrm{g}$ ) were analyzed by SDS-PAGE and detected with specific antibodies, anti-p-STAT3 (Tyr705), anti-STAT3 (total form), anti-SOCS3, and anti-SHP-1. Equal protein loading was confirmed by ERK expression.

실험을 통하여 전사억제제의 다른 기능적 연구가 필요할 것으 로 생각된다.

\section{Reference}

1. Chim, C. S., T. K. Fung, W. C. Cheung, R. Liang, and Y. L. Kwong. 2004. SOCS1 and SHP1 hypermethylation in multiple myeloma: implications for epigenetic activation of the Jak/STAT pathway. Blood 103, 4630-4635.

2. Choi W. H, K. A. Ji, S. B. Jeon, M. S. Yang, H. Kim, K. J. Min, M. Shong, I. Jou, and E. H. Joe. 2005. Anti-inflammatory roles of retinoic acid in rat brain astrocytes: Suppression of interferon-gamma-induced JAK/STAT phosphorylation. Biochem Biophys. Res. Commun. 329, 125 $-131$.
3. Elliott, J. 2008. SOCS3 in liver regeneration and hepatocarcinoma. Mol. Interv. 8, 19-21.

4. Federici, M., M. L. Giustizieri, C. Scarponi, G. Girolomoni, and C. Albanesi. 2002. Impaired IFN-gamma-dependent inflammatory responses in human keratinocytes overexpressing the suppressor of cytokine signaling $1 . J$. Immunol. 169, 434-442.

5. Frank, C., C. Burkhardt, D. Imhof, J. Ringel, O. Zschornig, K. Wieligmann, M. Zacharias, and F. D. Bohmer. 2003. Effective dephosphorylation of Src substrates by SHP-1. J. Biol. Chem 279, 11375-11383.

6. Fraschini, A., M. G. Bottone, A. I. Scovassi, M. Denegri, M. C. Risueño, P. S. Testillano, T. E. Martin, M. Biggiogera, and C. Pellicciari. 2005. Changes in extranucleolar transcription during actinomycin D-induced apoptosis. Histol. Histopathol. 20, 107-117.

7. Inghirami, G., R. Chiarle, W. J. Simmons, R. Piva, K. Schlessinger, and D. E. Levy. 2005. New and old functions of STAT3: a pivotal target for individualized treatment of cancer. Cell Cycle 4, 1131-1133.

8. Kang, H. J. and H. J. Park. 2009. Novel molecular mechanism for actinomycin D activity as an oncogenic promoter G-quadruplex binder. Biochemistry 48, 7392-7398

9. Kim, H., J. M. Suh, E. S. Hwang, D. W. Kim, H. K. Chung, J. H. Song, J. H. JH., Hwang, K. C. Park, H. K. Ro, E. K. Jo, J. S. Chang, T. H. Lee, M. S. Lee, L. D. Kohn, and M. Shong. 2003. Thyrotropin-mediated repression of class II trans-activator expression in thyroid cells: involvement of STAT3 and suppressor of cytokine signaling. J. Immunol. 171, 616-627.

10. Kim, H. K., M. Y. Kong, M. J. Jeong, D. C. Han, J. D. Choi, H. Y. Kim, K. S. Yoon, J. M. Kim, K. H. Son, and B. M. Kwon. 2005. Investigation of cell cycle arrest effects of actinomycin D at G1 phase using proteomic methods in B104-1-1 cells. Int. J. Biochem Cell Biol. 37, 1921-1929.

11. Kitsera, N., A. Khobta, and B. Epe. 2007. Destabilized green fluorescent protein detects rapid removal of transcription blocks after genotoxic exposure. BioTechniques 43, 222-227. 
12. Kleeff, J., M. Korman, H. Sawhney, and M. Korc. 2000. Actinomycin D induces apoptosis and inhibits growth of pancreatic cancer cells. Int. J. Cancer 86, 399-407.

13. Kumarswamy, R. and S. Chandna. 2010. Inhibition of microRNA-14 contributes to actinomycin-D induced apoptosis in Sf9 insect cell line. Cell Biol. Int. 34, 851-857.

14. Magdalan, J., A. Ostrowska, A. Piotrowska, I. Izykowska, M. Nowak, A. Gomułkiewicz, M. Podhorska-Okołów, A. Szelag, and P. Dziegiel. 2010. a-Amanitin induced apoptosis in primary cultured dog hepatocytes. Folia Histochem Cytobiol. 48, 58-62.

15. McWhinney, C. D., R. A. Hunt, K. M. Conrad, D. E. Dostal, and K. M. Baker. 1997. The type I angiotensin II receptor couples to Stat1 and Stat3 activation through Jak2 kinase in neonatal rat cardiac myocytes. J. Mol. Cell Cardiol. 29, 2513-2524.

16. Mitchell, T. J. and S. John. 2005. Signal transducer and activator of transcription (STAT) signalling and T-cell lymphomas. Immunology 114, 301-312.

17. Muller, P., D. Kuttenkeuler, V. Gesellchen, M. P. Zeidler, and M. Boutros. 2005. Identification of JAK/STAT signalling components by genome-wide RNA interference. Nature 436, 871-875.

18. O'Shea, J. J., M. Gadina, and R. D. Schreiber. 2002. Cytokine signaling in 2002: new surprises in the Jak/Stat pathway. Cell 109, s121-131.

19. Park, Y. J., E. S. Park, M. S. Kim, T. Y. Kim, H. S. Lee, S.
Lee, I. S. Jang, M. Shong, D. J. Park, and B. Y. Cho. 2002. Involvement of the protein kinase $C$ pathway in thyrotropin-induced STAT3 activation in FRTL-5 thyroid cells. Mol. Cell Endocrinol. 194, 77-84.

20. Samuel, W. and J. H. Douglas. 2004. Inhibitors of cytokine signal transduction. J. Biol. Chem 279, 821-824.

21. Shim, D, H. Y. Kang, B. W. Jeon, S. S. Kang, S. I. Chang, and H. Y. Kim. 2004. Protein kinase B inhibits apoptosis induced by actinomycin D in ECV304 cells through phosphorylation of caspase 8. Arch Biochem Biophys. 425, 214-220.

22. Szoor, B. 2010. Trypanosomatid protein phosphatases. Mol. Biochem Parasitol. 173, 53-63.

23. te Poele, R. H., A. L. Okorokov, and S. P. Joel. 1999. RNA synthesis block by 5, 6-dichloro-1-beta-D-ribofuranosylbenzimidazole (DRB) triggers p53-dependent apoptosis in human colon carcinoma cells. Oncogene 18, 5765-5772.

24. Yasukawa, H., M. Ohishi, H. Mori, M. Murakami, T. Chinen, D. Aki, T. Hanada, K. Takeda, S. Akira, M. Hoshijima, T. Hirano, K. R. Chien, and A. Yoshimura. 2003. IL-6 induces an anti-inflammatory response in the absence of SOCS3 in macrophages. Nat. Immunol. 4, 551-556.

25. Zhang, L., D. B. Badgwell, J. J. Bevers, K. Schlessinger, P. J. Murray, D. E. Levy, and S. S. Watowich. 2006. IL-6 signaling via the STAT3/SOCS3 pathway: Functional analysis of the conserved STAT3 N-domain. Mol. Cell Biochem 288, 179-189.

\section{초록 : 신장암 세포주에서 actinomycin D에 의한 SOCS3 발현 감소를 통한 STAT3 활성화 \\ 우선민 · 박은정 · 권택규* \\ (계명대학교 의과대학 면역학교실)}

본 연구에서는 전사억제제(transcriptional inhibitor)로 알려진 actinomycin D가 전사조절인자(transcription factor)인 STAT의 인산화를 유도한다는 것을 확인하였다. Actinomycin D 처리 시 STAT1의 Tyr701, Ser727 인산 화는 유도되지 않았지만 STAT3의 Tyr705 잔기의 인산화를 특이적으로 유도하는 것을 확인하였다. Actinomycin $\mathrm{D}$ 에 의한 STAT3의 Tyr705 인산화 유도가 어떠한 기전을 통한 것인지 확인하기 위해서 관련 인자의 단백질 및 $\mathrm{mRNA}$ 발현을 확인한 결과 SOCS3의 단백질 및 $\mathrm{mRNA}$ 발현의 감소를 확인하였다. STAT3의 탈인산화를 유도한 다고 알려진 tyrosine phosphatase인 SHP-1와 STAT의 upstream kinase인 JAK2의 인산화는 변화가 없었다. 또한 actinomycin D 뿐 아니라 다른 전사억제제인 DRB를 처리 하였을 경우에도 STAT3의 Tyr705 인산화가 유도되는 것을 확인하였다. 이상의 결과는 전사억제제에 의하여 특이적인 SOCS3 단백질 발현감소는 SOCS3의 하류의 target인 STAT3 인산화를 유도하였다. 